\title{
SPACE AND LANDSCAPE IN POLISH TOPONYMY
}

\author{
URSZULA BIJAK \\ Institute of Polish Language, Polish Academy of Sciences, Kraków, Poland
}

BIJAK, Urszula: Space and landscape in Polish toponymy. Jazykovedný časopis (Journal of Linguistics), 2021, Vol. 72, No 1, pp. $194-207$.

\begin{abstract}
In my paper I would like to analyze two sections of space: natural and cultural landscape (in terms of historical geography) and their reflection in the toponymic landscape. The greater focus will be on those elements of the natural landscape (the shape of the surface, soil, flora, fauna) and cultural landscape (forms and types of settlements, defense system, administrative divisions and borders, economic organization and trade, ownership, communication and roads), which were most often recorded and most frequently used in Polish oikonymy over the centuries.

Key words: Polish place names, natural landscape, cultural landscape, the most frequent topolexemes
\end{abstract}

\section{INTRODUCTION}

The terms space and landscape are used in many senses in colloquial language, as well as in scientific discussion. Space is a so-called travelling concept: it originated in philosophy, later to become the domain of geometrical, physical, geographical, historical, sociological, and linguistic studies. The situation regarding the term landscape is similar. Since these terms are largely ambiguous, the relations between them may be different depending on how broad the meanings we assign to them (Lisowski, 2003). Usually, in geographers' interpretation, space is defined as "that, which stretches everywhere, seems not to have any borders, and where all things and living creatures exist," while landscape is a real object, which takes up "a part of space," and partially fills it up (Plit, 2014, pp. 19-26). Settlement historians treat space as the sum total of social and political phenomena, and they research space, where historical events and processes take place. They determine what the historical geographical environment, that is, natural landscape, looked like; they analyze the processes which change a natural landscape into a cultural one (of settlement, politics, economy, communication, and military issues) (see Tyszkiewicz, 2014, pp. 57-157). Space as present in language, the ways in which people communicate concerning the spatial relations between objects and the spatial characteristics of objects, is an issue researched in the field of linguistics, including onomastics. In Polish linguistic studies, the terms linguistic space and linguistic landscape, onymic space and onymic landscape are 
used synonymously, and they refer in general to the linguistic expressions related to space and its different components.

In this paper, two parts of space will be analyzed: natural landscape and cultural landscape (as seen by historical geography), as well as their reflection cast in the toponymic landscape. The point of interest lies in those elements of the natural landscape (terrain, location, soil, plant life) and the cultural one (forms of settlement and types of dwellings arrangements, defense system, economic organization, roads), which were most frequently preserved in Polish toponymy throughout the ages. The statistical method, as well as instruments of cultural onomastics and cognitivism are used, particularly the linguistic picture of the world in Jerzy Bartmiński's view, which is defined as "a complex of opinions, which are more or less solidified in language, contained in the meanings or implied meanings of words, which determine the characteristics and modes of existence of the objects of the "non-linguistic world"" (Bartmiński - Tokarski, 1986, p. 72). The goal here is to present a fragment of the linguistic picture of the world, pertaining to the natural and cultural landscape, which is most frequently preserved in Polish oikonymy.

Modern Poland's toponymy comprises circa 124000 oikonyms, including 44000 city and village names, as well as 141000 anoikonyms, including 30000 hydronyms according to National Register of Geographical Names (PRNG). This contains names formed on the bases of appellatives, anthroponyms, and from other toponyms with the use of a wide range of name-forming means (onymization or semantic derivation, transonymization, pluralization, suffixation, compounding). Comprehensive data on the typology of settlement names is unavailable as yet, however partial data allows for the conclusion that appellative-based oikonyms are from 20 up to $40 \%$ of the general number of settlement names, depending on a certain territory. In this paper, I will concentrate only on the deappellative city and village names, created from the lexemes most frequently used in name formation. For this purpose, a list of modern oikonyms (44 000 names) and the historical material related to them, contained in the Nazwy miejscowe Polski. Historia. Pochodzenie. Zmiany [Place names of Poland. History. Origin. Changes] (NMPol) dictionary were analyzed, more precisely a rank list of ca. 100 most often used topolexemes, which appear in oikonymy with frequencies ranging between 30 and 700 times, was created. These are the bases of approximately 10000 settlement names (around $20 \%$ of the collection analyzed).

The most popular bases in that group can be categorized into a few semantic types. They are related to the natural properties of a given area: its shape, soil types, location, plant life, and hydrography, as well as with its material culture: settlement, economy, man-made objects (buildings, roads, or facilities).

My aim is to present here selected appellatives and settlement names motivated by them, which are most characteristic of the Polish natural and cultural landscape. 


\section{PRESENTATION OF THE SELECTED TOPONYMIC MATERIAL}

\subsection{Topolexemes related to a natural landscape}

\subsubsection{Land-related bases connected with terrain, topographical features,}

location, soil type

In toponymy, the most characteristic localizers in the vertical plane are the lexemes góra 'up/hill, mountain' - dót 'down, pit' and their derivatives, as well as wysoki 'high' - niski 'low'. This opposition is one of the oldest ones found in our culture. In the linguistic picture of the world, góra 'hill' is usually valued rather positively, even though it may also have ambivalent connotations, and dót 'pit' is perceived as unequivocally negative (SSSL I, p. 86; Adamowski, 1999; see also Myszka, 2016, pp. 380-381). This is reflected in the number of related oikonyms: names with bases of their meanings referring to góra (up), something in a higher location, are definitely more numerous than those related with dót (down).

The meaning located higher is connected with such appellatives as:

góra (<PSl. *gora) 'hill, mountain', present in oikonymy since the $12^{\text {th }}$ century, and found in more than 300 names, such as e.g. Góra, Góraj, Górecko, Góry, Górka, Górki, Góreczki, Górne, Górno, Górowo, Górzanka, Górzec, Górzno, Górzyca, Górzyn;

*chetm (< PSl. *chlms) 'hill, high ground' reconstructed from toponymy, noted since the $10^{\text {th }}$ century, represented in such names like Chetm, Chetmy, Chetmiec, Chetmce, Chetmno, Chetmsko, Chetmek;

garb (< PSl. *grbz) 'hillock' documented since the $13^{\text {th }}$ century, e.g. Garby, Garbacz, Garbno, Garbów, Garbatka;

grad (< PS1. *grod $)$ ) 'elevated, dry place in the marshes, with firm ground, forested', registered since the $14^{\text {th }}$ century, e.g. Grad, Grady, Gradzik, Gradziki;

kepa (< PSl. *kopa) 'elevated place in a wetland, or cluster of trees or bushes', etymologically an elevation, something placed above its surroundings (SEBor, p. 227), noted since the $13^{\text {th }}$ century, e.g. Kepa, Kepy, Kepie, Kepno, Kepina, Kepino, Kepiste; very often as compound names Kepa Chwałowska;

wierzch ( $<$ PSl. *vrrchb) 'mountain, top', in written documents since the $14^{\text {th }}$ century, e.g. Wierzch, Wierzchy, Wierzchowina, Wierzchowiny, Wierzchowiska, Wierzchowo;

adjective wysoki 'in a high place', e.g. Wysocze, Wysoka, Wysokie.

Antonymic names related to dót (< PSl. *dolb) 'lower part of something' have been noted since the $13^{\text {th }}$ century in such oikonyms as e.g. Dót, Doty, Doleck, Dolice, Dolsk, Dólsk, Dołki; compound names Suchodót, Sudół.

There are also derivatives of dolina 'valley', e.g. Dolina; podole 'valley', e.g. Podole, Podolin; adjective dolny 'lower', e.g. Dolna, Dolnik, and synonym niski 'located in the lower place', e.g. Niskie Wielkie, Nisko. But these bases and names 
were found to be much less frequent. Geographical distribution of names motivated by appellatives góra 'hill' - dót 'pit' is presented on the map 1. Oikonyms derived from góra 'hill' base can be found all over the country, not only in the southern part of Poland, which is mountainous.

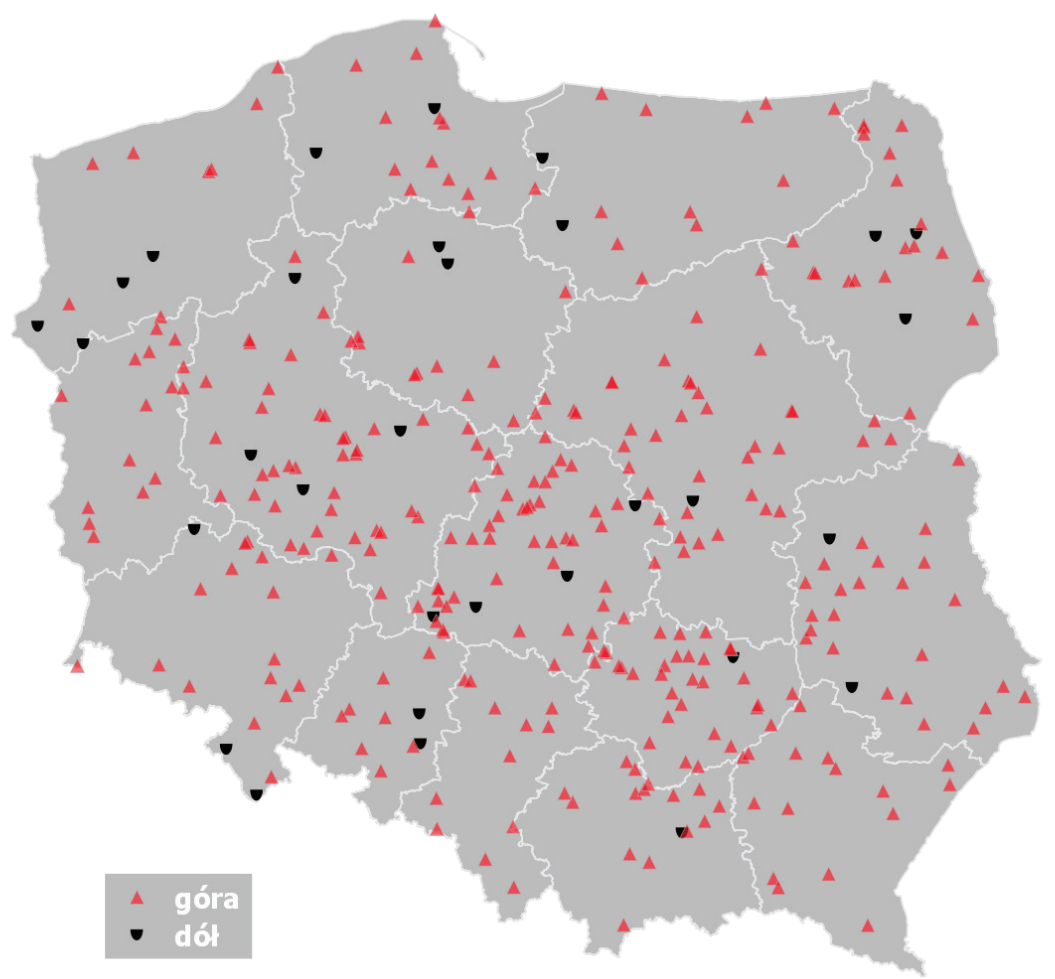

Map 1: Góra ('up, hill') and dót ('down, pit') in Polish oikonymy ${ }^{1}$

In the horizontal plane, the most frequently referred-to domain related to spatial phenomena is the przód-tyt ('front-back') opposition. In toponymy, this opposition is realized by the use of the prepositions pod ('nearby', in toponymy more likely 'before', 'in front of', 'by') and $z a$ ('behind something'), which occur in more than 300 and ca. 400 names respectively, e.g. Podgórze (from the adverbial phrase pod góra, 'by the mountain'), Podlas (: pod lasem 'by the forest'), Podgaj (: pod gajem 'by the grove'), Podborze (: pod borem 'by the [coniferous] forest'), and Zarzecze (: za rzekq 'beyond the river'), Zagórze (: za góra 'behind the mountain'), Zagaje (: za gajem 'behind the grove').

${ }^{1}$ All maps were created by Paweł Swoboda. 
Among land-related names, the base taka (< PSl. *loka) 'meadow, grassland' is very frequent, it was first noted in the $13^{\text {th }}$ century, in such names as e.g. Eaka, Eaki, Łęki, Łącko, Łaczka, Łączki, Łąkta, and also appellative ostrów (< PSl. *o(b)strovz) 'island, field located between meadows and ditches, overgrown with plants' (SEBor, p. 401), in historical sources since the $12^{\text {th }}$ century, e.g. Ostrów, Ostrowy, Ostrowo, Ostrówiec, Ostrowce, Ostrówek, Ostrówki, Ostrowite.

Other frequent bases include descriptions of soil type are:

kamien' (< PSl. *kamy) 'pebbly place', registered since the $13^{\text {th }}$ century, e.g. Kamień, Kamion, Kamienica, Kamieniec, Kamienna, Kamieńczyce;

piasek (< PSl. *pěsъkъ) 'sandy place', in historical sources since the $13^{\text {th }}$ century, e.g. Piasek, Piaski, Piaseczna, Piaszczyna;

glina (< PSl. *glina) 'clay, kind of yellow impermeable soil, used for the production of bricks and ceramics', noted since the $12^{\text {th }}$ century, e.g. Glina, Gliny, Glińcz, Glińsk, Gliniak, Glinica, Glinice, Glinik, Glinnik, Glinki, Glinianka, Glinisko, Glinne.

\subsubsection{Plant bases - names of trees, bushes, wooded or overgrown areas}

Trees are an indispensable element of space; they have a practical, economic function, however, in many cultures they had magical functions as well. In Polish folklore, the popular image of the world considers some trees as good and lucky (oak, lime tree and birch) or evil and unlucky (like willow, aspen); strong and powerful (oak, beech) or weak (willow, aspen) (Moszyński, 1967, pp. 516-532). The frequency list of most common oikonymic bases from this semantic field has the appellative $d a b$ 'oak' at the first place (along with its derivatives, ca. 600 names), other high-frequency terms include brzoza 'birch', lipa 'lime tree', grab 'hornbeam', olcha 'alder', buk 'beech', osika 'aspen', grusza 'pear tree', jesion 'ash', jabłoń 'apple tree', wierzba 'willow', jawor 'sycamore', choina 'coniferous tree', sosna 'pine', wiśnia 'cherry', cis 'yew', jodta 'fir', świerk 'spruce' (see also Makarski, 2006, pp. 96-97). The order of tree names here is analogous to the number of oikonyms derived from them. The same bases are also found on the list of the most frequent hydrolexemes in river names of the Vistula basin, even though their order is different (Bijak, 2013, p. 211). Frequently arboreal hydronyms would be re-used as oikonyms, too.

The predominance of the base $d a b$ 'oak' in the formation of Polish toponyms is the result, on the one hand, of the tree's frequent role as part of the natural landscape, and on the other, of its important place in folklore - the oak was perceived as the world tree with especially rich symbolism (Marczewska, 2002, p. 138). This appellative is the centre of the most extensive oikonymic nest. The list comprises names formed directly from the appellative $d a b$ 'oak tree', e.g. Dacb, Decby, Dęba, Dębe, Dąbie, Dębie, Dębna, Dębno, Dębiec, Dębicz, Dębicze, Dębieniec, Dębina, Dębiny, Dębinka, Dębinki, Dębianki, Dębionka, Dębowa, Dębowe, Dębowo, Dębów, 
Dębowica, Dębowiec, Dębówka, Dębsk, Dębsko, Dębieńsko; dąbek 'small oak tree', e.g. Dąbek, Dąbki, Dębki, Dębczyna, Dąbkowice, Dąbkowo, and compound names, e.g. Dębogóra, Dęborzeczka, Dębowa Łąka, Dębów Dziat, Dębowy Grunt but mainly those formed from derivatives denoting places where such trees grow, groups of oaks, oak forests and groves like: dębnik, e.g. Dębnik, Dębniki; dębniak, e.g. Dębniak, Dębniaki; dębica, e.g. Dębica, Dębice; dębnica, e.g. Dębnica; dąbrowa 'deciduous forest or thicket, mostly oaks', e.g. Dąbrowa, Dąbrowy, Dąbrówka, Dąbrówki, Dąbrusk (<Dąbrowsko); *dąbrowica 'oak grove, thicket', Dąbrowica (see also Nowik, 1994, pp. 94-98, Makarski, 2006, pp. 60-71, 96). Similar naming models (even though not so productive) represent nests with other tree names as their centres. Geographical distribution of settlement names motivated by the appellative $d a b$ 'oak' and its derivatives is presented on map 2. These type of oikonyms can be met all over the country, more often in the central Poland.

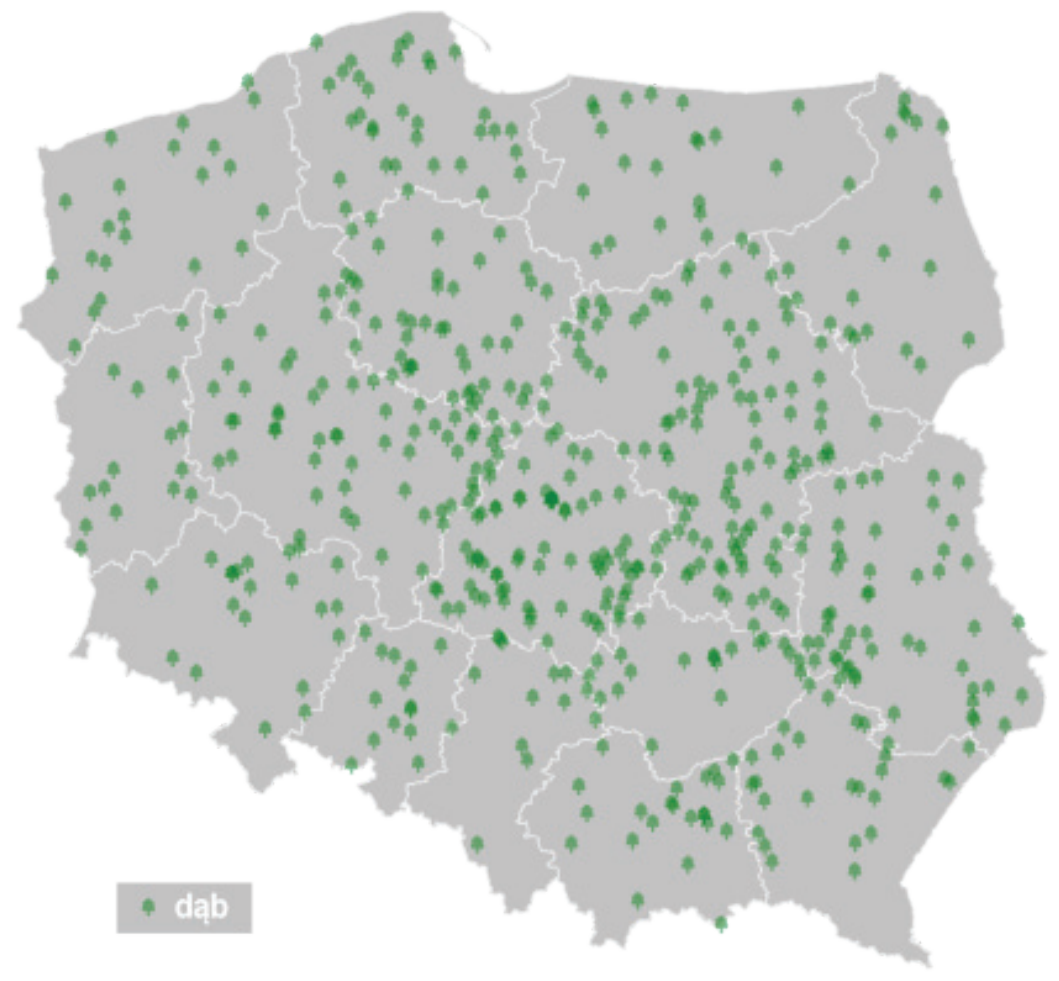

Map 2. Dąb 'oak' in Polish oikonymy

Apart from tree type names, oikonyms are frequently based on general words meaning large concentrations of trees or forested areas, the most general being las 
'forest, wooded area (mainly deciduous trees)'; e.g. Las, Lasek, Laski, Laskowa, Laskowiec, Laskowo; bór 'large, thick, old coniferous forest'; also 'forest' in general (with derivatives), e.g. Bór, Borowo, Borów, Borowo, Borowiec, Borek, Borki, Boreczek; gaj 'grove, small young forest, most frequently deciduous, group of wildgrowing trees' (with derivatives), e.g. Gaj, Gajew, Gajewo, Gajewiec, Gajowice, Gaik. Toponyms of this type were formed since the earliest times until modern times, and they may provide a lot of information concerning historical tree stands in Poland.

Names of bush or other plant species would also become bases of oikonyms. Here, the following may be distinguished:

tarn (< PSl. *trnz) 'thorny bush', 'thorny scrub', e.g. Tarnawa, Tarnowa, Tarnów, Tarnica, Tarniny, Tarnobrzeg, Tarnowiec;

trześć, trzścina, trzcina (< PSl. *trbstb, *trbstina; SEBor, p. 648) 'reed', e.g. Trzciana, Trzcino, Trzciany, Trzcianka, Trzcianki, Trzciel, Trzcinica, Trzciniec, Trzcińsko;

mech (< PSl. *mbchb) 'moss, Muscus plant', e.g. Mchawa, Mchowo, Mchy, Mechnica, Mechnice, Mechowiec, Mechowo, Mochnaczka (Ukr.), Mochnate (Brus.), Moszna, Mosznica, Mszadla, Msza(d)lnica, Mszane, Mszanne, Mszanowo;

chmiel (< PSl. *chomelb, oriental loanword; SEBor, p. 63) 'hop, Humulus plant', e.g. Chmiel, Chmiele, Chmielek, Chmielewo, Chmielnik, Chmielniki, Chmielno, Chmielowiec, Chmielówka;

kalina (< PSl. *kalina) 'Viburnum, bush growing on wetlands', the oldest oikonym is dated to the $13^{\text {th }}$ century: Kalina, Kalina Wielka, Kalinowa, Kalinowo, Kalinowiec;

laska (< PSl. *lěska) 'hazel, Corylus avellana bush', leszczyna 'hazel bushes, thicket', e.g. Leszcze, Leszczanka, Leszczany, Leszczyca, Leszczyna, Leszczyny, Leszczyniec, Leszno (noted since the $13^{\text {th }}$ century), Leszczydót.

\subsubsection{Water-related bases, referring to hydrographic terms, names of water and wetlands}

In the linguistic picture of the world, water is seen as a force of good, it symbolizes life and fertility, even though it can also be a destructive force (SSSL I, p. 153), it is necessary for human life, which is why early settlements developed along rivers.

The most general hydrographic name woda, 'water', is not very frequent in oikonymy (even in hydronymy), it is used with additional terms of water or riverbed color (like biała 'white', czarna 'black', czerwona 'red'), water quality (dobra 'good', zimna 'cold'), e.g. Biała Woda, Białowody, Czarna Woda, Czerwona Woda, Dobrowoda, Zimna Woda, Zimne Wody.

Bases, which are hydrographic terms, especially meaning still waters, are more frequent, e.g.:

jezioro (< PSl. *ezero) 'lake', e.g. Jezioro, Jeziora, Jeziory, Jezierce, Jeziernia, Jeziernik, Jezierzany, Jezierze, Jezierzyce, Jezierzysk, Jeziorzec, Jeziorna, Jeziorek, Jeziorko, Jeziorki, Jeziórki, Białe Jeziorki; 
staw 'pond', e.g. Staw, Stawy, Stawce, Stawiec, Stawiska, Stawiski, Stawiszcze, Stawno.

There are also names related to running waters:

rzeka (< PSl. *rěka) 'river', e.g. Rzechta/Rzekta (: rzekta 'small river'), Rzecko, Rzeczka, Rzeczyca, Rzeczyce, Rzeczyn;

stok (< PSl. *jbztokъ; SEBor, p. 578) 'downward flow’, e.g. Stok, Stoki, Stock, Stoczek, Stoczki, Stokowo;

as well as to wetlands and marshes:

błoto (< PSl. *bolto) 'mud', e.g. Błoto, Błota, Błotnica, Błotnik, Białe Błota;

kat (< PSl. *kalb) 'mud, swamp', e.g. Kały, Kalsk, Kałek, Kaliska, Kaleń (since the $14^{\text {th }}$ century).

The oikonyms mentioned above are related to appellatives denoting nearby bodies of water (frequently non-extant in the modern era), whose proper names are not noted in written sources. However, the frequent village names with the adjective bystry 'fast, running' in their basis, such as Bystra, Bystre, Bystrzyca, originate directly from hydronyms, since the basis is semantically connected with movement primarily relating to water.

Among oikonymic bases, adjectives such as biaty 'white', czarny 'black', czerwony 'red' also stand out; these may refer to the color of ground and type of soil. However, in the light of historical documents, it can be seen that at last a few place names are motivated directly by soil properties or color; most of them are derived from water-related names based on these adjectives, e.g. the oikonyms Biała, Białka, Czarna, Czarne, Czerwonka were formed by transonymization from the hydronyms Biała, Białka, Czarna, Czarne, Czerwonka.

The situation is different with names created from the adjective glęboki 'deep', like Gtębock, Gtębocz, Gtęboka, Gtębokie. Even though the basis is one of the most frequent in hydronymy, only few such oikonyms are derived from hydronyms; most are formed directly from the adjective głęboki, which can also refer to a lower part of the terrain, or a dell.

\subsection{Topolexemes related to cultural landscape}

\subsubsection{Bases referring to the forms of settlement}

Among topolexemes related to cultural landscape, the most frequent bases are signified by types of settlements.

The medieval privilege, which exempted new settlers from paying taxes to the land's owner, found its way into place names derived from the words wola $(<\mathrm{PSl}$. *vol'a, Lat. libertas) and lgota 'relief, lower payment'. Oikonyms of the types Wola, Wólka, Wolica and Lgota, Ligota were formed as early as the $12^{\text {th }} / 13^{\text {th }}$ centuries, and are geographically diverse (PNW, p. 220). Lgota is typical generally for Silesia region and its borderland of Great and Lesser Poland and Wola, Wólka especially for Mazovia region. Not all names of the type Wola, Wólka are of medieval origin; in 
later centuries the appellative wola became a synonym of the word wieś 'village'. The geographical distribution is presented on the map 3.

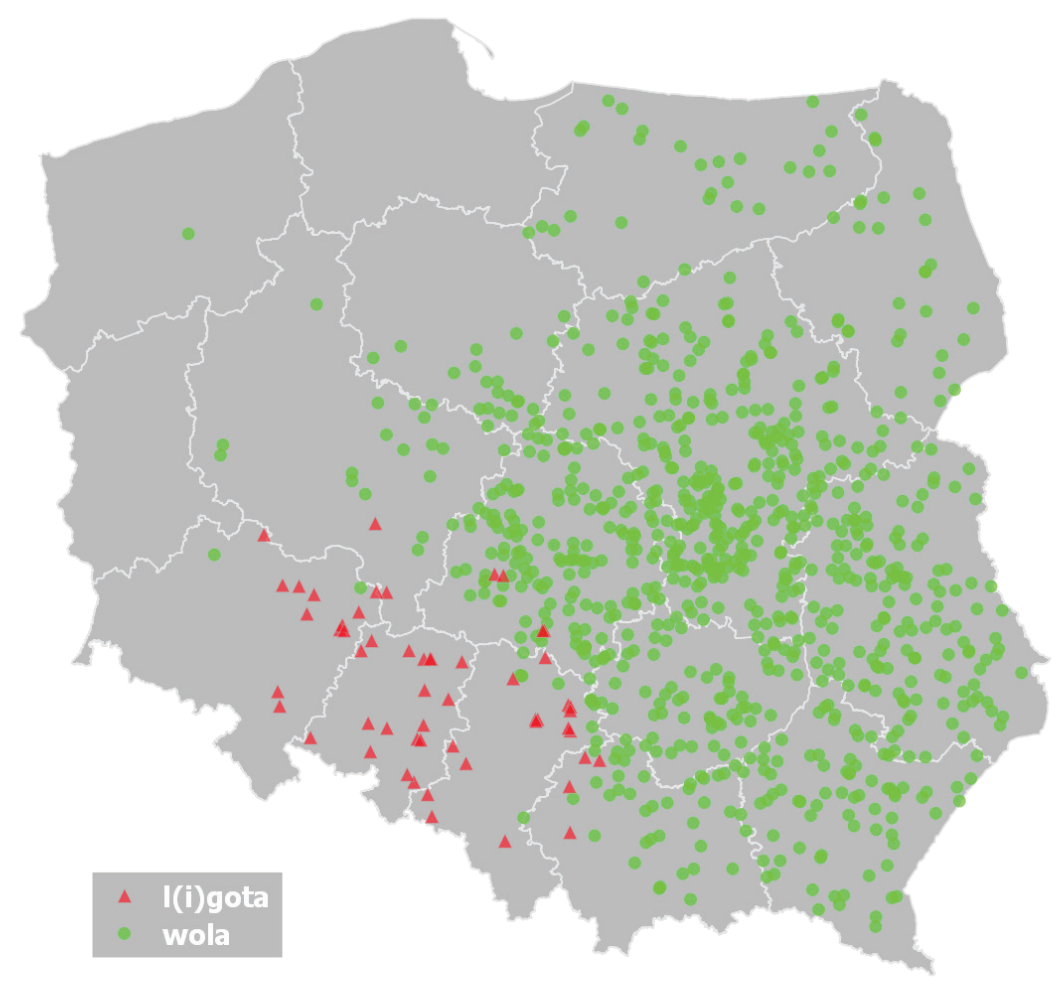

Map 3. Wola, l(i)gota in Polish oikonymy

The appellative wieś (<PSl. *vbsb) 'village' is also widespread in oikonymy, it is mainly a part of compound names, frequently in conjunction with adjectives: stary 'old' - nowy 'new', e.g. Stara Wieś, Nowa Wieś, also maty 'small' - wielki 'great', e.g. Mała Wieś, Wielka Wieś. These names refer to the time of the settlement's founding, its division into parts, or its size.

A high level of frequency is also observed with the synonymic name *siodto $(<$ PSl. *sedlo; SEBor, p. 548), sioto 'village', in oikonymy since the $12^{\text {th }}$ century, e.g. Siedlec, Sielc, Siedlce, Sielce, Siedlice, Siedlica, Siedlin, Siedliska (: siedlisko), Siedliska, Siedliszcze, Siodto, Siodta. Geographical distribution of oikonyms motivated by the appellatives wieś and sioto is presented on the map 4. 


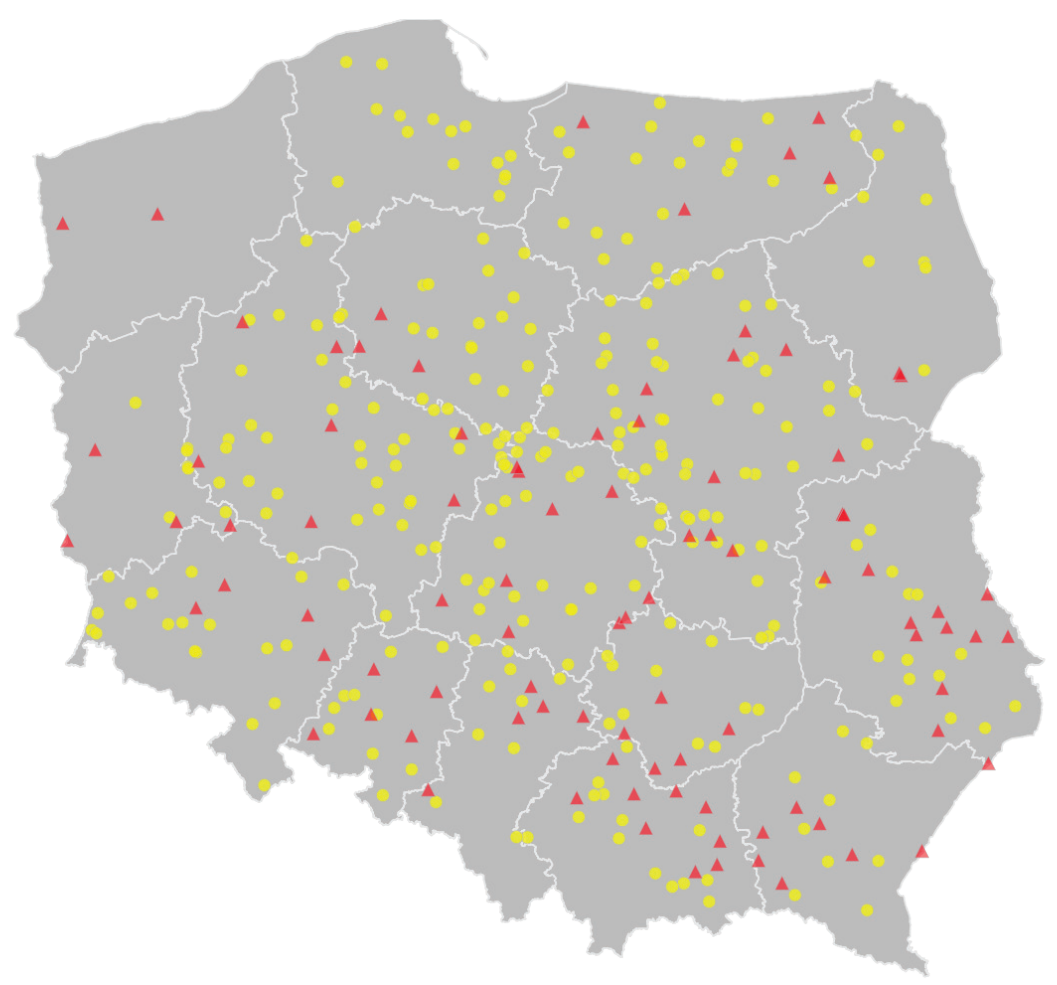

siodlo wiés

Map 4. Wieś, sio(d)to 'village' in Polish oikonymy

The more recent naming stratum comprises names formed on the basis of the appellative buda of German origin ( $<$ Middle High German büde, boude), meaning 'a small building, forest settlement, primitive wood processing plant; poor village'; in toponymy since the $16^{\text {th }}$ century, e.g. Buda, Budy, Budki, Budzisko, Budziska, frequently in compounds such as Budy Kozickie (see also Wójcik, 1991); and from the appellative majdan (loan from Turkish maydan 'square, yard', in Polish perhaps via Ukrainian) 'forest settlement whose inhabitants were engaged in woodworks, charcoal or tar production', in toponymy since the $18^{\text {th }}$ century, e.g. Majdan, Majdany, Majdanek. Settlements of this type are found in the former Russian partition (see also Czopek, 1984). Their geographical distribution can be seen on the map 5. 


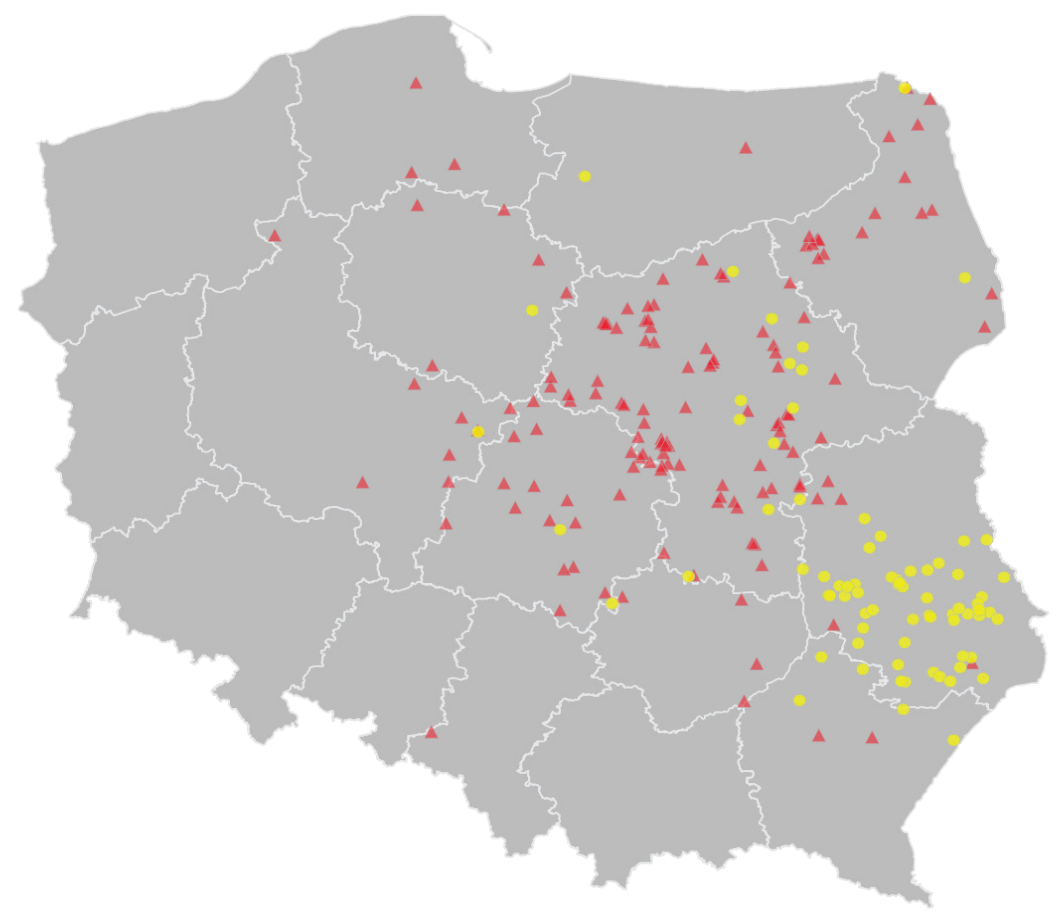

$\triangle$ buda majdan

Map 5. Buda, majdan 'forest settlement' in Polish oikonymy

\subsubsection{Bases related to the communications network and the defense system}

Among topolexemes based on cultural terms, appellatives related to the medieval communications network and roads are particularly frequent:

bród (<PSl. *brodz) 'ford, place where the river is shallow and can be crossed on foot or on horseback', present in oikonymy since the $13^{\text {th }}$ century, e.g. Bród, Brody, Brodek, Brodki, Brodna, Brodnica, Brodowo;

most (< PSl. *mostъ) 'bridge' and its derivative mościć (PSl. *mostiti 'to build a bridge or road'), noted in place names as early as the $13^{\text {th }}$ century, e.g. Mosty, Mostek, Mostki, Mostowo, Mostówka, Moszczenica;

stup (< PSl. ${ }^{*}$ stlp $\left.b\right)$ 'pillar, kind of medieval road sign marking the middle of the road, ca. $20 \mathrm{~km}$ between castellan seats, fortified cities', noted as oikonym since the $13^{\text {th }}$ century, e.g. Stup, Stupy, Stupia, Stupca, Stupcza, Stupie, Stupiec, Stupno, Stupowa, Stupowo, Stupów, Stupsk.

Following the traces of military landscape are bases related to the medieval defense system: 
gród (< PSl. *gord ‘ 'fortified city', etymologically 'fenced place') 'fortified settlement, located so it is difficult to reach', oikonyms derived from this base are noted in sources since the $12^{\text {th }}$ century, e.g. Grodno, Grodnica, Grodziec, Grójec, Gródek, Grodzisk, Grodziszcze;

osiek (< PSl. *o(b)sékъ) 'fortification made of cut-down trees', in written sources since the $12^{\text {th }}$ century, e.g. Osiek, Osieki, Osieck, Osiecko.

\subsubsection{Bases related to the medieval economy}

With medieval farming, the way forests were turned into arable land by the slash-and-burn practice, are connected such lexemes as:

$t a z$ 'arable land in a burnt-out place', in Polish documents since the beginning of the $13^{\text {th }}$ century, e.g. Laz, Lazy, Lask, Lazisko, Laziska;

żary (< PSl. *žarb) 'settlement created on the place where forest was burnt away', noted since the $13^{\text {th }}$ century, e.g. Żar, Żary;

$z d \dot{z} a r, \dot{z} d \dot{z} a r$ 'forest or scrub burnt out to make room for agriculture', e.g. $\dot{Z} d \dot{z} a r$, Żdżary (Zierhofferowie, 2009, pp. 93-117);

with forest clearings: poręba 'place where forest was cut down', documented since the $14^{\text {th }}$ century, e.g. Porab, Poręba, Poręby, Porabki.

Lexemes referring to specialized production are also well-represented:

mbyn (from Old High German mulin; SEBor, p. 332-333) 'mill' is noted in the $13^{\text {th }}$ century, e.g. Młyny, Młynek, Młynki, Młyniec, Młynik, Młyniki, Młyniska, Młyńczysko, Młynkowo, Młynków, Młynne;

kuźnia (< PSl. *kuznbja) 'forge, blacksmith's workshop', as an oikonym since the $15^{\text {th }}$ century, e.g. Kuźnia, Kuźnica;

ruda (< PSl. *ruda 'rusty mud, later transferred to bog iron'), 'primitive metallurgical works, where iron was smelted and processed', usually together with an open-pit mine of bog iron, in oikonymy since the $12^{\text {th }}$ century, e.g. Ruda, Rudka, Rudna, Rudno, Rudnia, Rudnica, Rudnicze, Rudnik, in the modern era frequent in compounds such as Ruda Talubska.

Kuźnia, kuźnica and ruda were synonyms, and in the oikonymic material there are frequent notes like Lipieńska Ruda (1519), Kuźnia (1787) or Minera alias Kuźnica (1550), Rudy albo Kuźnice (1564) in different periods, referring to the same settlement (NMPol V, p. 510, 511). Another basis (and the last one to be mentioned here) related to metal or glass production is huta (loan from Middle High German hütte; SEBor, p. 197) 'foundry, ironworks', present in oikonymy since the $15^{\text {th }}$ century, e.g. Huta, Hutki, Hutków, Hucisko, Huciska, Hucina, in the modern era frequently in compounds such as Huta Jagodnicka.

The above-mentioned oikonyms related to specialized production are mainly noted after the $16^{\text {th }}$ century, even though some of them are already found in written sources from the medieval period. 


\section{CONCLUSION}

The article describes ca. 50 topolexemes related to the natural and cultural landscape, out of the 100 appellatives most frequently found in modern Polish oikonymy. They represent such semantic fields as topography, plant life, settlement, defense and communications systems, and economy. These are mainly words of Slavic origin, few of them, especially ones of cultural characteristics, are loans from German dialects (like buda, mlyn, huta).

Oikonyms formed from these appellatives were created through: onymization of a singular appellative or a plurale tantum, pluralization, suffixal derivation with the topoformants such as: *-bje, -ica, -ec, -ek, -ka, -ko, -ik, -isko; -sk-, -in-, -ow-, $*_{-}-b n-$, and compound formation. The presence of these topographical and cultural settlement names in the onymic landscape of Poland is permanent, and they were being formed throughout all the historical periods.

Place names are linguistically recorded elements of natural landscape and of the cultural landscape created by humans, in part of the landscapes currently observed, but also of those, which have already disappeared, and are preserved in language. These introduced in my text are the most characteristic factors of Polish toponymic landscape. They stratify space, and have been transmitting landscapes and places throughout the centuries.

Abbreviations

Brus. $=$ Belarussian; Lat. $=$ Latin; PSl. $=$ Proto-Slavic; Ukr. $=$ Ukrainian.

References

ADAMOWSKI, Jan: Dół w ludowym obrazie świata (pochodzenie i lokatywność). In: Językowy obraz świata. Ed. J. Bartmiński. Lublin: Wydawnictwo UMCS 1999, pp. 155182.

BARTMIŃSKI, Jerzy - TOKARSKI, Ryszard: Językowy obraz świata a spójność tekstu. In: Teoria tekstu. Zbiór studiów. Ed. T. Dobrzyńska. Wrocław: Zakład Narodowy im. Ossolińskich 1986, pp. 65-81.

BIJAK, Urszula: Nazwy wodne dorzecza Wisły. Potamonimy odapelatywne. Kraków: Instytut Języka Polskiego PAN 2013. 308 p.

CZOPEK, Barbara: Apelatyw majdan w toponimii polskiej. In: Onomastica, 1984, Vol. XXIX, pp. 69-89.

LISOWSKI, Andrzej: Koncepcje przestrzeni w geografii człowieka. Warszawa: Uniwersytet Warszawski 2003. 198 p.

MAKARSKI, Władysław: Nazwy najpopularniejszych drzew w Polsce jako baza toponimiczna. In: Roczniki Humanistyczne, 2006, Vol. LIV, No 6, pp. 57-100. 
MARCZEWSKA, Marzena: Drzewa w języku i w kulturze. Kielce: Wydawnictwo Akademii Świętokrzyskiej 2002. 248 p.

MOSZYŃSKI, Leszek: Kultura ludowa Słowian. T. 2. Kultura duchowa. Cz. 1. Warszawa: Książka i Wiedza 1967. 827 p.

MYSZKA, Agnieszka: Urbanonimia Rzeszowa. Językowo-kulturowy obraz miasta. Rzeszów: Wydawnictwo Uniwersytetu Rzeszowskiego 2016. 497 p.

NMPol = RYMUT, Kazimierz - CZOPEK-KOPCIUCH, Barbara - BIJAK, Urszula (eds.): Nazwy miejscowe Polski. Historia. Pochodzenie. Zmiany. T. I-XV. Kraków: Instytut Języka Polskiego PAN 1996-2018.

NOWIK, Krystyna: Das Topolexem dąb im polnischen Namenschatz. In: Namenkundliche Informationen, 1997, Vol. 71/72, pp. 94-98.

PLIT, Florian: Krajobraz w przestrzeni czy przestrzeń w krajobrazie. In: Prace Komisji Krajobrazu Kulturowego, 2014, Vol. 24, pp. 19-24.

PNW = Polskie nazwy własne. Encyklopedia. Ed. E. Rzetelska-Feleszko. Warszawa Kraków: Instytut Języka Polskiego PAN 1998. 543 p.

PRNG = Państwowy Rejestr Nazw Geograficznych. Online: https://www.geoportal.gov. $\mathrm{pl} /$ dane/panstwowy-rejestr-nazw-geograficznych. [accessed 20.10.2019]

SEBor = BORYŚ, Wiesław: Słownik etymologiczny języka polskiego. Kraków: Wydawnictwo Literackie 2005. $861 \mathrm{p}$.

SSSL $=$ Słownik stereotypów i symboli ludowych. T. 1. Kosmos. Ed. J. Bartmiński. Lublin: Wydawnictwo UMCS 1999. 481 p.

TYSZKIEWICZ, Jan: Geografia historyczna. Zarys problematyki. Warszawa: Wydawnictwo DiG 2014. 354 p.

WÓJCIK, Urszula: Baza bud-w toponimii polskiej. In: Onomastica, 1991, Vol. XXXVI, pp. 73-81.

ZIERHOFFEROWIE, Karol i Zofia: Refleksy gospodarki żarowej w polskim nazewnictwie. In: Onomastica, 2009, Vol. LIII, pp. 93-117. 